DOI https://doi.org/10.30525/978-9934-588-92-1-26

\title{
ДЕЯКІ АСПЕКТИ СУЧАСНОГО КОНСТИТУЦІОНАЛІЗМУ В ПРОВІДНИХ КРАЇНАХ СВІТУ
}

\author{
Охотнікова О. М. \\ кандидат юридичних наук, дочент, \\ доцент кафедри конституиійного, \\ адміністративного та кримінального права \\ Навчально-наукового інституту \\ «Юридичний інститут ДВНЗ «Київський начіональний економічний \\ університет імені Вадима Гетьмана» \\ Фоміна Н.-A. Б. \\ здобувач магістерського рівня вищої освіти \\ Навчально-наукового інституту \\ «Юридичний інститут ДВНЗ «Київський наџіональний економічний \\ університет імені Вадима Гетьмана» \\ м. Київ, Україна
}

Проблема сучасного конституціоналізму $\epsilon$ актуальною як для провідних країн світу, так і для тих, що розвиваються, та потребує всебічного вивчення. При цьому очевидним $є$ те, що попри спільні цінності та подібну структуру конституціоналізму у розвинених країнах, його практичне втілення й конституційні системи різняться.

В умовах триваючої конституційної реформи в Україні важливо визначити пріоритети у формуванні національної моделі конституціоналізму. Дослідження розвитку сучасних конституційних моделей у світі $є$ вкрай важливим для можливого запозичення досвіду, що дозволить врахувати позитивні досягнення щодо зазначеної проблеми в зарубіжних країнах та запобігти допущенню помилок в українському конституційному будівництві. Конституціоналізм і різні його аспекти були предметом дослідження багатьох учених, зокрема I. Бойка, О. Бориславської, А. Крусян, В. Речицького, М. Савчина, М. Томенка, С. Шевчука. Їхні праці були присвячені різним аспектам формування, становлення і розвитку конституціоналізму в Україні та світі. Попри це вбачається за необхідне проведення порівняльного аналізу сучасних моделей конституціоналізму, виділення їх основних спільних та відмінних рис.

Метою дослідження $€$ порівняльний аналіз американської та європейської моделей конституціоналізму на прикладі Сполучених Штатів Америки і Франції, а також з'ясування їх характерних особливостей. 
Традиційно науковці виділяють такі моделі конституціоналізму: американська, англо-саксонська та європейська (континентальна).

Для розкриття особливостей європейської моделі конституціоналізму обрано Францію, чиє конституційне будівництво зробило великий внесок у розвиток світового конституціоналізму. Деякі науковці, зокрема Савчин М.В., навіть виділяють окрему французьку модель у межах ліберально-демократичного конституціоналізму, основними характерними рисами якої $\epsilon$ сильна президентська влада, раціоналізований парламентаризм та обмежена роль конституційної юстиції.

В американській моделі конституціоналізму простежується визначення людської свободи й індивідуального вибору як вищої цінності та гарантується невтручання держави у сферу індивідуальної свободи - на відміну від Західної Європи, де наразі пріоритетними цінностями виступають рівність і солідарність. Крім цього, як стверджує В. Речицький, у США «державна влада повинна відігравати службову роль по відношенню до громадянського суспільства i не зупинятися перед застосуванням сили з моральних міркувань» [4, с. 22].

При цьому доречно було б зупинитись на англійській моделі, яка хоч і має схожість з американською, $є$ при цьому унікальною з огляду на відсутність писаної конституції, конституціоналізм при цьому ототожнюється 3 принципом верховенства права та спирається на потужні інтерпретаційні й контрольні повноваження судів, що $\epsilon$ засобом обмеження законодавчої влади [3, с. 65]. На наш погляд, такі риси англійського конституціоналізму не можуть бути притаманні конституціоналізму в Україні.

Саме тому показовими для України моделями сучасного конституціоналізму вбачаємо американську та європейську.

Варто відзначити, що американська та європейська модель мають спільні елементи, які, в свою чергу, забезпечують і реалізацію та практику конституціоналізму. Можна виділити такі елементи: 1) писана конституція; 2) юридично закріплені права людини; 3) конституційна юрисдикція, 4) незалежна судова влада; 5) поділ влади на незалежні гілки.

При цьому писана конституція є характерною рисою як американської, так і європейської моделі конституціоналізму. Попри те, що кодифікована конституція присутня в обох країнах, концепції їх розвитку різняться. Як обгрунтовано стверджує О.М. Бориславська, в США дискусії головним чином зосереджені навколо питання стабільності Конституції 1787 року, яка діє до сьогодні [1, с. 179]. В континентальній Європі, на відміну від Англії та США, процес конституціотворення продовжується, відтак проблема установчої природи конституції залишається актуальною. Як зазначає М.В. Савчин, для Франції загалом притаманне ведення 
постійних політичних дебатів 3 приводу майбутньої побудови інститутів влади [5, с. 37].

Наступним елементом, що притаманний обом моделям конституціоналізму, є конституційна юрисдикція, яка служить системою юридичного захисту Конституції і забезпечує дієвість верховенства права та захист конституційного ладу.

При цьому в США конституційна юрисдикція $є$ видом судової діяльності, де відсутній спеціальний орган конституційної юрисдикції, натомість відповідні функції здійснює Верховний суд Сполучених Штатів. Конституційна юрисдикція в Америці стосується вирішення конкретних спорів та має більше відношення до правосуддя, ніж до законотворчості [2 с. 101].

Для європейської моделі конституціоналізму у Франції характерна наближеність конституційної юрисдикції до законотворчості, адже рішення суду, яке скасовує неконституційний закон, є своєрідним актом законотворчості. У Франції органом конституційної юстиції $\epsilon$ Конституційна рада.

Слід зазначити, що забезпечення, гарантування та захист основоположних прав людини й громадянина - це характерний елемент $\mathrm{i}$ американської, і європейської моделі конституціоналізму. Як зазначає О.М. Бориславська, «їх гарантування $є$ підставою для встановлення чітких рамок для функціонування держави, діяльності ії органів, накладення на державну владу відповідних конституційних обмежень» [1, с. 221].

Аналізуючи обсяг основоположних прав і свобод в американській та європейських моделях конституціоналізму, доцільно порушити питання ідеологій, які лежать в основі цих моделей. На сьогодні існують дві реалізовані на практиці відмінні ідеології конституціоналізму - лібералізм та ліберальна демократія.

Країнам із європейською моделлю конституціоналізму, зокрема Франції, притаманна ідеологія ліберальної демократії, головною ідеєю якої $€$ запровадження такого типу урядування, де основоположні права людини i громадянина та вимоги верховенства права обмежують сферу демократичного ухвалення рішень. Американський конституціоналізм відображає ідеологію лібералізму, орієнтовану на права та свободи індивіда як найвищу цінність та максимальне невтручання держави у сферу індивідуальної свободи.

Відмінності в ідеологіях зумовлюють також особливості основоположних прав у американській та європейській моделях. Так, наприклад, для американського лібералізму притаманне мінімальне втручання держави у сферу свободи людини, що зумовлює зміст основоположних прав у Сполучених Штатах. Прикладом тут виступає широка свобода висловлення, під захист якої потрапляє навіть мова ворожнечі. Також, 114 
конституційне правосуддя в США відкидає будь-яку можливість утисків поглядів. Водночас в умовах європейської моделі конституціоналізму таке обмеження права на вільне вираження поглядів можливе. До прикладу, у рішенні ЄСПЛ «Леїде та Ізорні проти Франції» було встановлене правило щодо можливості покарання за заперечення голокосту й нацистської пропаганди [6].

Наступним елементом виступає ефективне виконання судовою владою iii функцій, яке можливе лише за умови іiі незалежності, незалежно від моделі конституціоналізму. Незалежність судової влади вважається універсальним принципом, визнаним на рівні ООН. Виходячи $з$ доктрини конституціоналізму, суди повинні бути повністю незалежні від органів законодавчої влади, діяти не як інструменти обраного більшістю законодавчого органу, а як слуги конституційного ладу взагалі [1, с. 258].

Слід вказати, що відмінними особливостями судової влади в США $є$ те, що вона формувалася 3 нуля, як і сама держава, й була незалежною та наділеною широкими повноваженнями від самого початку свого існування. У свою чергу, в Свропі, у тому числі й у Франції, судочинство традиційно належало до прерогатив монарха. Тож на європейському континенті необхідним було забезпечити незалежність судів від глави держави, парламенту та уряду $[1,259]$. Наразі, на наш погляд, визначальну роль для організації судової влади в межах європейської моделі сучасного конституціоналізму мають стандарти незалежності судової влади, розроблені на рівні Ради Свропи.

Висновки. Таким чином, відмінності між моделями сучасного конституціоналізму в США та Франції зумовлені доктринальними особливостями, що по-різному визначають природу Основних законів держав, конституційної юрисдикції, обсягу основоположних прав людини та громадянина, незалежності судової влади.

При цьому слід зазначити, що ідеологія американської моделі сучасного конституціоналізму ще не є близькою до українських реалій, а також має суттєві відмінності в структурі та механізмах функціонування конституційно-правових інститутів, на відміну від європейської моделі, до якої тяжіє розвиток сучасної національної конституційної думки та практики.

На шляху євроінтеграційних процесів, ми вважаємо, що доцільним буде запозичити деякі елементи французької моделі конституціоналізму, при цьому з якомога більшим послабленням президентської влади.

\section{Література:}

1. Бориславська О.М. Європейська модель конституціоналізму: формування, сучасний стан, тенденції розвитку: дис. ... д-ра юрид. наук. Харків, 2019. 428 с. 
2. Бориславська О.М. Конституційна юрисдикція в умовах європейської моделі конституціоналізму. Право Украӥни. 2018. № 4. C. 93-107.

3. Бориславська О.М. Роль органу конституційної юрисдикції у формуванні в Україні системи конституціоналізму європейського зразка: до постановки проблеми. Вісник Конституційного Суду України. 2014. № 3. С. 62-71.

4. Речицький В. Конституціоналізм. Коротка версія: (читанка 3 конституціоналізму для зацікавлених). Харків: Права людини, 2014. $262 \mathrm{c}$.

5. Савчин М.В. Конституціоналізм і природа конституції: монографія. Ужгород: Поліграфцентр «Ліра», 2009. 372 с.

6. Lehideux and Isorni v. France, № (55/1997/839/1045, ECHR, URL: https://www.legal-tools.org/doc/2fed5c/pdf/

DOI https://doi.org/10.30525/978-9934-588-92-1-27

\title{
ПРОБЛЕМИ ЗАБЕЗПЕЧЕННЯ ПРАВ ЛЮДИНИ І НАЦІОНАЛЬНОЇ БЕЗПЕКИ В УМОВАХ ІНФОРМАЦІЙНОГО СУСПІЛЬСТВА
}

\author{
Роскошний I. B. \\ acnipaнm \\ Харківського національного університету імені В. Н. Каразіна \\ м. Харків, Україна
}

Бенджамін Франклін, один із батьків-засновників Сполучених Штатів Америки, одного разу заявив на Асамблеї штату Пенсільванія, що «ті, хто готовий пожертвувати наявною свободою заради малої частки тимчасової безпеки, не гідні ні свободи, ні безпеки» [1]. Це твердження зберігає свою істинність та актуальність і дотепер, оскільки основні права i свободи кожної людини мають бути захищені незалежно від часу, місця чи обставин. У XXI ст. загрози національній безпеці набувають якісно нових форм, відповідно розвиваються i загрози правам людини. Система захисту національних інтересів від небезпек змушена адаптуватися до нових викликів, тому на благо нації й 3 метою захисту ii від загроз, як внутрішніх, так i міжнародних, держави змушені вдаватись до відповідних заходів. Цілком зрозуміло, що деякі 3 них мають правообмежувальний характер або, принаймні, 